Premiere Educandum: Jurnal Pendidikan Dasar dan Pembelajaran

Volume 8(2) 112 - 126 Desember 2018

Copyright (C2018 Universitas PGRI Madiun

ISSN: 2088-5350 (Print) / ISSN: 2528-5173 (Online)

Available at: http://e-journal.unipma.ac.id/index.php/PE

Doi: 10.25273/pe.v8i2.2739

\title{
Character education implementation for students in grade IV SDN 5 Sindangkasih regency of Purwakarta West Java
}

\author{
Sofyan Mustoip \\ Universitas Negeri Jakarta \\ email: sofyanmustoip@gmail.com
}

\begin{abstract}
Students are less polite especially to teachers who should be respected. The sense of courtesy can be seen when the students shaking hands to the teacher he met, and say "excuse me" when passing the more mature person, and the number of learners who use slang compared to use sundanese. Thus, this study has the aim to describe in full the pattern of implementing character education as an effort of Elementary school in carrying out character education activities for students in grade IV in order to shape the character of students through the local wisdom of Sundanese culture. The method used in this study is a qualitative descriptive method that uses an interactive model in data analysis activities including data collection activities, data reduction, data presentation, and conclusion drawing. Data collection was carried out through data triangulation, namely interviews, observation, and documentation. The research subjects consisted of one school principal, three class teachers, one school guard and all fourth grade students. The results showed, the character values pursued by that school's are religious values, discipline, independence, respect for achievement, communicative, and responsibility. This is in accordance with the vision and mission of SDN 5 Sindangkasih which is to create a school that is capable of producing superior generations who are religious, mastering science and technology, and loving Indonesian culture.
\end{abstract}

Keywords: Students, Local Wisdom, Qualitative Methods.

Histori artikel : disubmit pada 07 Juli 2018; direvisi pada 14 Agustus 2018; diterima pada 12 September 2018

\section{A. INTRODUCTION}

Education in Indonesia is in line with National Education objectives has an orientation to produce a broader generation (knowledgeable) through optimizing every potential learners and forming human beings of character as well as having faith, noble character, physical and spiritual health, independent, creative, democratic and responsible answer.

The paradigm of today's Indonesian society, seeing the western state as a developed country, when western culture entered Indonesia, some societies were unable to filter out the outside cultures that contradict the prevailing cultural values in Indonesia. In this case, it is clear that the effect can give a negative impact on learners both from their attitude and behavior. This is in line with Judiani's opinion (2010:280) in his research on the implementation of character education in elementary school that, "Learners at the present time, have no manners, likes brawl, liquor, narcotics, and racing on the highway".

The above phenomenon suggests that character education is very urgent to apply especially in Early Childhood Education to Primary Schools, as learners of this age, need moral education that can translate abstract principles of right and wrong, in order to be 
preventive in overcoming attitude and behavior problems on the scope of education. This is in line with Hurlock's opinion (2015:123) that, "Moral development in early childhood is still at a low level, so it has not been able to apply abstract principles of right and wrong."

Character education in elementary schools, should get more attention to form the noble moral foundations of strong learners. This is done, so that learners have awareness about the importance of good values and have a commitment to always do good on the next education and in everyday life.

Optimization in education, will shape the personality of good learners in sorting and choosing relationships, actions, and actions in accordance with applicable norms. This, it gives a positive impact for future generations in order not easily influenced outside culture and the environment is not good. The implementation is expected to be able to print the leading generation for Indonesia gold in 2045 which transformed Indonesia into advanced and dignified.

Based on the results of interviews with principals and teachers of state primary school 5 Sindangkasih, the following data are obtained: principals and teachers argue that today, learners prefer outside cultures to their own culture in terms of clothing, behavior, or language used. Learners often buy snacks during break times outside school, and immediately play after school home without going home first to ask permission parents and change school uniforms. This becomes a dilemma for the school and parents, because in recent times there are rampant cases of kidnapping children and drug sales through food favored learners, so it is necessary to implement character education that is able to preventive in addressing the character problems in state primary school 5 Sindangkasih.

In the implementation of character education, each school has its own school culture, which is the hallmark of its school. In this case, the research will be conducted in state primary school 5 Sindangkasih which implements character education with school culture which emphasizes the existence of the aspects of the value of the daily delay in school.

The culture of state primary school 5 Sindangkasih: entering school at 06.00 WIB, bringing stock from home, wearing Sundanese clothes, using Sundanese language and not to bring the vehicle to school, all of which are implemented based on character education theme every day.

The theme of character education that is applicable in state primary school 5 Sindangkasih is as follows:

a. Monday, relating to the growing sense of nationality or love of the homeland;

b. On Tuesday, it deals with broadening the horizons of the world;

c. On Wednesday, it relates to a return to identity as a Sundanese;

d. Thursday is concerned with providing space for the freedom of expression and caring for others;

e. Friday, relates to getting closer to God Almighty;

f. Saturday and Sunday, deals with loving home as a family home. (Wulandari, 2017) 
Thus, character education in state primary school 5 Sindangkasih has had a concept in implementing character education, as an effort to train intellectuals to be broad-minded and improve the character of learners. This study aims to describe in full the implementation of character education for students of class IV in state primary school 5 Sindangkasih, when learning takes place in the classroom and when students do free activities outside the classroom.

\section{Character Education}

Education character is a conscious effort to instill and develop good values in order to humanize human beings, to improve character and train students' intellectuals, so that a generation of knowledge and character can be created that can benefit the surrounding environment. This, in line with Zubaedi's (2015), "Character education is the deliberate effort to cultivate virtue that is objectively good human qualities that are good for the individual and good for the whole society."

The above opinion is also reinforced by Lickona's statement in Easterbrooks \& Scheets (2004) that, "Character education is the deliberate effort to develop the virtues that are good for the individual and good for society". Thus, it is clear that character education is a systematic effort to develop virtues that positively impact both individuals and the social environment, and the process is not instantaneous, but through continuous effort (habituation).

Planting habituation from an early age, is one of the main efforts to optimize the implementation of character education, through the synergy of all components of the school in shaping the character of students through the cultivation of values that are accustomed to goodness. Thus, schools have a very important role in the development of students' character, in line with Kohlberg (in Horn, Daddis, \& Killen, 2008) who formulated that, "There are two conditions that can stimulate children's development related to character. First, discussion in the formal context (curriculum). Second, forming school culture as a moral environment".

The statement above, can be understood that character education will be more effective, if students are able to actively participate in their social environment (school), then there is active support from the teacher. This is done, to encourage and develop intelligence in thinking, appreciation of attitudes, and experiences based on character values through moral principles that apply as a form of student identity.

Thus, in implementing character education in elementary schools, a careful planning is needed, in this case Lickona (2001) divides it into three stages, namely "knowing morality, moral feeling, and moral action". A, the explanation is as follows:

a. Moral knowing is moral knowledge, related to how one can know good and bad things. The dimensions included in this moral knowledge are cognitive domains, including moral awareness, knowledge of moral values, courage to take attitude, and self-recognition.

b. Moral feeling, namely the strengthening of emotional aspects to shape one's character, including: awareness of identity, confidence, sensitivity to the suffering of others, love of truth, selfcontrol, and humility. 
c. Moral Action, which is a moral action that results from moral knowledge and moral feeling. To fulfill this, students must have three aspects of character, including: competence, desire, and habits. These three aspects of character need to be possessed to direct someone to a moral life, because all three will form moral maturity.

Character education does not only make students intelligent but also to form personalities to conform to the norms that apply in the area where they live.

\section{Characteristics of Learners}

Character of students is a selfidentity that is owned by every student. In this case, the character of students in grade IV is strongly influenced by environmental factors. This is in line with Erikson's opinion (in Slavin, 2011) that, "Students of elementary school age are in stage IV, namely the period of grandeur versus inferiority". At this time, the school and community environment is very influential on the development of students' character.

The role of a teacher in instilling character values is needed at this time, to filter out cultures that are not good enough to enter the school and influence students. Success from the time of grandeur versus inferiority is to make students become individuals who are confident in doing and making things, and their failure will make students become shy individuals and create a negative self-image, which can hamper future learning.
Students at the elementary school age are in the stage of boyhood. This period is indicated, among others; students behave actively and savage stage or often known as "stubborn". Period Boyhood is a child period of 7-14 years who actively moves, jumps and runs freely without knowing the risks involved. This is in line with Rousseau's opinion (in Kusnaedi, 2013) that, "Boyhood is a savage stage, this stage reflects the stage of wild evolution. Students at this time, move a lot, jump and run freely to train the sharpness of their senses, but the ability of the mind is still lacking ".

Characteristics of students in the fourth grade aged between 10-11 years, generally have a more relaxed, calm nature, even tend to be busy with themselves and see everything with their point of view. This, in line with Gessel's opinion (in Kusnaedi, 2013) that, "Students aged 10-11 years are relaxed, calm, busy with themselves, every desire always wants to be fulfilled, always wants to ask questions, and see everything only from his perspective".

Thus, in educating elementary school students, a teacher must provide education based on the stages of the natural development of students. This is intended, so that students can more easily understand the substance of ongoing learning.

The moral development of elementary school students, considers that a rule is something that is approved by everyone, and if everyone agrees to change it, then the rule can be changed. In this case, a teacher must provide guidance regarding the planting of character values, so that students remain in the corridor of goodness.

Primary School students, tend to see right or wrong not from the punishment, but from the purpose of the perpetrator. This is in 
line with Piaget's opinion (in Kusnaedi, 2013) that, "Children at the age of elementary school tend to base moral judgments on the perpetrators' intentions rather than the consequences of actions".

The morality of students continues to grow along with the widespread social world of students, as well as the increasing number of peers they have. Student morality development is carried out through interaction and collaborating continuously with peers, so the rule is something that can be made or changed, and the sentence can be adjusted based on considerations of the purpose of doing so.

Character is basically categorized as self quality development. In this case, there are several factors that influence the development of self quality, including: innate factors (nature) and factors nurture. In this case, what is meant by "carriage is the biological transmission of genetic characteristics from parents to their descendants, and the environment encompasses all conditions in this world which in certain ways affect a person's behavior" (Lestari, 2011).

The carrier factor includes the characteristics of students based on the characteristics of their parents. The purpose of the environment is the conditions encountered by students, including: the school environment, community environment, and family environment that can influence the behavior and attitudes of students.

According to Ratnawati (2015) in research on factors that influence character education shows that, "The character of each individual is influenced by internal factors and external factors". The descriptions are as follows:

a. Internal factors

factors are factors that can be a supporter or inhibitor that comes from within the individual. This factor is related to soft skills interpersonal(one's skills in dealing with others) and intrapersonal (self-regulating skills) that students have.

b. External Factors

factors are factors that are influenced by the surrounding environment. External factors that play an important role in the formation of students' character, among others: family environment, school environment, and community environment.

Based on the above explanation, the characteristics of students is an identity that every student has as a potential from birth, and develops through an educational process about the socialization of values. In its development, the characteristics of learners are influenced by internal factors (innate) and external factors (family, school, and community environment) that continue throughout life.

\section{Relevant Research}

a. Research Safitri's research on the implementation of character education through school culture shows that, routine activities in schools are carried out by all school residents continuously and consistently. Routine activities carried out, among others: 3S Culture, namely smile, greetings, and greetings; Schools hold regular activities for Muslims, and for non-Muslim students there is religious guidance; Dzuhur prayer congregation; Sing the national anthem before learning begins; Friday prayers in congregation; Regular 
ceremony every Monday; Mutual cooperation cleanses the environment and makes organic fertilizer; Care for the environment by cleaning the environment both inside and outside the classroom; and $4 \mathrm{~K}$ programs, namely Cleanliness, Discipline, Order, Security.

b. Buchory \& Tulus's research on the implementation of character education in junior high schools shows that, planning and organizing character education in junior high schools is carried out by principals, vice principals, and all teachers; the implementation was fully supported by all school residents and their supervision was handed over to the deputy head of school for curriculum and student affairs, the supervisor of the Student Council, STP2K, and counseling teachers by working together.

c. Rukiyati \& Andriani's research on local wisdom-based character education models at the Elementary School shows that, teachers have succeeded in implementing a value-planting strategy for character education through traditional Javanese songs. The song, sung with the game movements of students and teachers. The values contained in Javanese traditional songs can be well understood by students, including: (1) bald songs (good, humble, responsibility); (2) slukusluku bathok (love for God, obedience to worship, generous, cooperation; (3) jaranan (respect and courtesy, responsibility, discipline, cooperation); (4) menthog-menthog (good and humble, peace, confidence) (5) Lir-Ilir (love of God, responsibility and discipline; (6) Kidang Talun (eating procedure, praying before meals); (7) Padang Bulan (not sleeping late afternoon, cooperation) and (8) Dondong Apa Salak (obedient to parents, not fussy and not naughty)

d. Ajat Sudrajat and Ari Wibowo's research on the formation of commendable characters at SD Muhammadiyah Condongcatur shows that, character building programs and their implementation practices going well through the commendable character building programs include: (1) quality school culture, (2) Islamic school culture, and (3) discipline culture.Kongno's

e. research on the integration of character education in learning shows that, Integration of character education in the eyes Communication lecture Interpersonal has been able to increase students' understanding of the value of noble characters. This is indicated by the increase in the four aspects of noble character, namely courtesy, openness, empathy, and equality.

If previous studies have a positive influence on the formation of personality of students, it is predicted that the implementation of character education for students in grade IV SDN 5 Sindangkasih will be able to provide positive results in the formation of students' character through habituation in accordance with school culture. 


\section{B. METHOD}

Implementation of character education for students in class IV state primary school 5 Sindangkasih, will be examined using descriptive qualitative research method is "research method used as a research procedure that produces descriptive data" (Fuad \& Kandung, 2014:54). Thus, researchers will collect data and data will be processed in the form of descriptive, ie in the form of words and images obtained from interviews, documentation, field notes and other supporting documents.

Sources of data in this study are principals, teachers, school employees, and learners. Researchers will conduct interviews, observation and documentation of participants regarding the character education phenomenon applied in the fourth grade of state primary school 5 Sindangkasih. This is done as an attempt to present the social world based on the participants' perspective in terms of concepts, behavior, perceptions, and issues about character education, so that researchers can describe the implementation of character education for students in the fourth grade of state primary school 5 Sindangkasih comprehensively.

The research procedure is done through the initial observation stage, formulating the problem, determining the research method and design, conducting literature study, doing direct observation, collecting data, analyzing data, and making research report. Technique of data collecting done by triangulation of data that is interview, observation, and documentation (Moleong, 2014).
Researchers analyzed data by using interactive models Miles and Huberman, can be understood with the picture as follows:

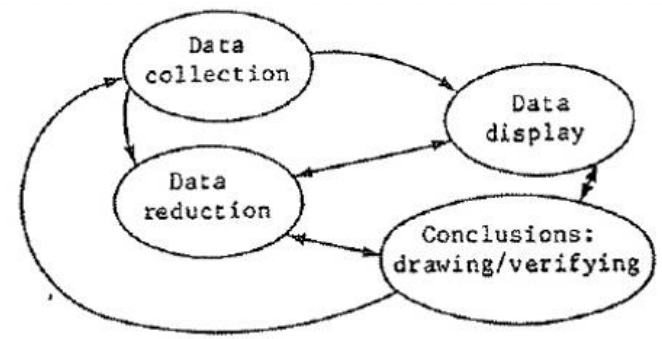

Figure 1. Data Analysis Interactive Model (Fuad \& Kandung, 2014)

Data that researchers collect through various methods of data collection, among others: observation, interview, and documentation are data in the form of descriptive. The data are then analyzed simultaneously through three paths, namely: data reduction, data presentation, and conclusion / verification.

As for checking the validity of the data, the researcher uses the technique based on the table as follows:

Table 1. Development of Engineering Examination (Bungin, 2014)

\begin{tabular}{|c|c|}
\hline CRITERIA & $\begin{array}{c}\text { TECHNICAL } \\
\text { EXAMINATION }\end{array}$ \\
\hline $\begin{array}{l}\text { Credibility of } \\
\text { the researcher } \\
\text { (degree of } \\
\text { trust) }\end{array}$ & $\begin{array}{l}\text { 1. Extension of } \\
\text { participation } \\
\text { 2. Finding cycle of } \\
\text { similarity of data } \\
\text { 3. Perseverance } \\
\text { observation } \\
\text { 4. Triangulation } \\
\text { honesty researcher } \\
\text { 5. Checking through } \\
\text { discussion } \\
\text { 6. Negative case review } \\
\text { 7. Member checking }\end{array}$ \\
\hline $\begin{array}{l}\text { Credibility } \\
\text { method of } \\
\text { collection } \\
\text { data }\end{array}$ & $\begin{array}{ll}\text { 8. } & \text { Triangulation } \\
\text { methods } \\
\text { 9. Triangulation of data } \\
\text { sources }\end{array}$ \\
\hline $\begin{array}{l}\text { Theoretical } \\
\text { and referential } \\
\text { credibility }\end{array}$ & $\begin{array}{l}\text { 10. Triangulation theory } \\
\text { 11. Reference adequacy }\end{array}$ \\
\hline Certainty & 12. Detailed description \\
\hline
\end{tabular}


Dependence 13. Audit

\section{FINDING AND DISCUSSION}

\section{Teacher Planning in Preparing} Learning in Character Education Classes

Based on the findings of the field it can be seen that the fourth grade teacher at SDN 5 Sindangkasih plans the implementation of character education in the form of learning implementation plans (RPP) by incorporating character values in each learning step.

The planning is adjusted to the culture and development of students in grade IV so that learning can run effectively and efficiently in accordance with what is needed in classroom learning. This is in line with Sumantri's opinion (2016) that, 'Learning planning is a written text composed of the results of a systematic analysis related to the development of students so that learning can be more effective and efficient in accordance with the needs of students and the community'.

In the explanation above, it can be seen that the planning of learning becomes something very urgent because it can be used as a guide or guide for carrying out learning activities, so that whether or not learning can be seen from the plan. In this case, in addition to mastering the concepts that students must master, the class teacher also includes and optimizes the contents of character values in each learning plan so that not only smart but also faithful, noble, and daring people do good.

\section{The Implementation of Inside and Outside Class Character Education.}

\section{a. Bringing students to school}

This program is carried out because there are school rules that, students who use school uniforms are not allowed to bring their own vehicles to school let alone motorized vehicles. This is intended to minimize the level of accidents among students.

As for students who violate it, they don't go up as a sanction. A school rule must be obeyed by all school residents to maintain security, cleanliness and order in the school environment, in line with Hadianti (2008) who revealed that "school rules can be interpreted as ties or rules that must be obeyed by every school member where the learning process takes place".

Thus, the implementation of a school rule will run well when teachers, school principals, school employees and students work together to run the rules. To carry out these rules, the parents or siblings of the students have the responsibility to deliver their sons and daughters to school as a form of parental love for their children.

\section{b. Entrance Program 6th Hour}

This program is a habit that is expected by the school so that students are accustomed to getting up early, performing morning prayers, and learning in an atmosphere that is still cool. The school thinks that with students accustomed to early morning prayer, when they are in school their attitude will be controlled and easily directed towards the good because salat can prevent evil and evil actions. In line with Qur'an Surah $\mathrm{Al}$ 'Ankabut verse 45 which reads as follows:

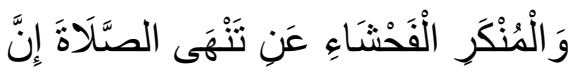


Meaning: "Verily the prayer prevents from evil and evil deeds." (Religious department of the Republic of Indonesia, 2016:401)

This program is very useful for the health of students to get used to breathing clean air in the morning. In addition, this morning wake-up activity is an activity to preserve and preserve the local wisdom of Sundanese culture.

Thus, the school wants to revive the values of local wisdom which has begun to fade contaminated with outside culture. In the Sura of the Qur'an above, you can understand that there is an order to perform prayers and scatter on the face of the earth to seek the gift of Allah, including by seeking useful knowledge.

\section{c. Welcomes Learners Program}

Welcomes students program is a program to be a role model for students, because basically the teacher is a figure that is worthy of being praised and imitated meaning that each teacher's behavior, attitude, and speech is noticed and imitated by their students. Thus the teacher must be a good example for his students.

Exposure above is in line with the opinion of Bandura in Crain that, 'Learners in social situations are much faster in learning something just by observing the behavior of others, especially people who are more mature than him'. Thus, a teacher needs to give an example of exemplary in the formation of student character, this is done by the teacher, one of them is by implementing a program to welcome students every day. The program was conducted to give examples of discipline to go to school, share the enthusiasm in the morning by smiling to students because in Islam the smile of fellow Muslims is worth alms. In harmony with Izudin (2014) who revealed that "Smiles are done sincerely to please others, including in the category of alms".

In addition, the teacher also gives examples of being friendly, and teaches students to behave politely by getting used to shaking hands when meeting a teacher, saying greetings when entering a room, and saying punten when passing older people. Habituation is expected to be a character that internalizes in each student.

\section{d. Clean Environment Love Program Clean}

environmental love program is an activity to familiarize students in terms of loving cleanliness. The activities are the distribution of picket schedules, class cleaning before and after learning, storing shoes outside the classroom, tidying up shoes stored outside, and checking for neatness.

This program has an important role in shaping the character of students who are clean, and care for the environment. With this habituation, students can design their own environment to feel comfortable, so that learning can be more meaningful. Furthermore, developing countries like Indonesia have very urgent problems related to waste and hygiene issues. This is in line with Erwati (2013) who revealed that "Developing countries and developed countries have in common, namely in environmental issues, but the cases and causes are different. If in developed countries the causes are industrial wastes, then in developing countries like Indonesia the causes are household waste and human waste".

Based on the explanation above, it becomes something that this program needs to be implemented. This is an effort from the education sector, especially the school, to 
foster and train better future generations, care for the environment, and love hygiene through habituation which is expected to be internalized in students and able to be applied in daily life.

\section{e. Shared Meal}

Program This joint eating program is intended to maintain the intake of food consumed by students, so that students can avoid food containing harmful substances. In addition, students are also taught to tolerate each other, not to mock the food brought by his friends because fellow Muslims are brothers and mock that disgraceful act that will make his friend's heart hurt. This is in line with the word of God in Surah Al-Hujurat verse 10 which reads:

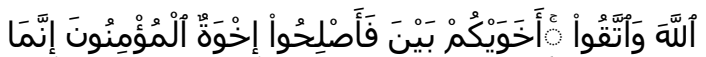
تُرْحَمُونَ لَعَلََكُكْمْ

Meaning: indeed those who believe are brothers. Therefore, make peace (improve relations) between your two brothers and fear Allah, so that you may receive mercy (Religious department of the Republic of Indonesia, 2016).

Al-Qur'an verse above, it can be understood that Allah told to maintain good relations with others (friends). By maintaining good relationships, there will be a feeling of mutual affection, social caring, unity and unity among friends, so that in the end students can support each other in terms of goodness, including supporting the achievement.

This program is very interesting to do in elementary school. In addition to fostering an attitude of unity and unity of students, this program also has usefulness in fostering a sense of empathy for students.

\section{f. Program Using Typical Sundanese Clothing on Tuesdays and Wednesdays}

This program has the goal that students know Sundanese clothing, so that from this stage of knowing students will understand that the culture belongs to Sundanese people who must be maintained and developed by future generations so as not to be eaten era. This activity needs to be done, because Indonesia is an archipelago country that has a lot of cultural heritage and local wisdom.

Cultural heritage and local wisdom will disappear along with the times, if no future generation cares about it. In line with Nisafani's research (2014:1), "Indonesia is rich in cultural heritage and local wisdom. However, the majority of the population is less concerned and lacks knowledge and understanding of their culture because of the lack of information".

Thus, the provision of information about regional culture must be programmed from an early age. SDN 5 Sindangkasih is very enthusiastic in promoting character education programs that emphasize the existence of values of misery in daily life at school. This can be seen from the character environment, so SDN 5 Sindangkasih has a Sundanese style.

\section{g. The Program Awake Getting Selfon Friday}

This program has the meaning of closer to God Almighty. The most perfect. This self-purifying activity includes all activities that are Islamic-charged and leads to religious values, such as: getting up early to perform morning prayers, listening to Islamic studies on the school grounds, training in 
sunnah duha prayers, praying before and after learning, and wear Muslim clothing.

Islamic studies are led by religious teachers, whose activities are giving Islamic lectures with material according to the development of students, such as: prayer, recitation, fasting, alms, and stories of the Prophet Muhammad. This study was carried out to provide additional knowledge about Islam which is not necessarily obtained when in class, in harmony with the Bukhori Hadith History (in Rosinta, 2018:37) which reads "Convey from me even if only one verse".

For the sunnah duha prayer training, the class teacher collaborates with religious teachers in terms of guiding and conditioning students, so that students can carry out the prayer training properly and correctly, and do not joke during the sunnah prayer training.

\section{h. Vocational Program}

Program This vocational program is an activity carried out by the classroom teacher to visit students' homes in order to find out the family situation of students, in terms of the economy, employment, latest education, and informal education provided in the family. Thus there will be a collaboration between the teacher in charge of the school, and parents who provide education to students when at home.

In this case, the form of cooperation between parents and teachers is to monitor the learning progress of students, the involvement of students in educating their children, and the participation of parents in enforcing school rules so that students will follow the rules that apply at school. This is in line with Hidayat's statement (2013:95), "Cooperation between parents and teachers is a communicative relationship to monitor the development of students during the teaching and learning activities".

Good cooperation between parents and teachers can produce good influences, including parents' trust in the teacher to educate their children while in school, parents can help students in matters that have not been mastered by students from the results of the academic reports submitted by the teacher during vocational visits, and teachers can communicate actively with parents of students to synergize in educating students to be intelligent and characterized children.

\section{The Role of School Principals, Teachers, and School Guards}

Synergy between school residents, especially principals, teachers, and school guards as executors of character education programs at SDN 5 Sindangkasih, must go well. In this case, the principal has a role to provide direction related to the implementation of character education, being a good partner for teachers at Sindangkasih Elementary School 5, as well as a leader who is able to protect and maintain relationships with school citizens to remain in the same vision and mission. This is in line with Setiyati (2014:202) that, "The principal is someone who determines the center point and rhythm of a school, because the school is a complex entity that requires coordination".

Thus, it is clear that the role of the principal is the rhythm regulator as well as the policy maker in the school with regard to the culture and program of the school. In addition to the principal, who is no less important is the teacher, because the teacher 
is the implementer of character education that is close to students and almost all the time is always with students when they are in the school environment.

The teacher has a role to apply character education directly to students, both in the classroom and outside the classroom. In this case, the teacher is the determinant of whether or not the character education is implemented at SDN 5 Sindangkasih. This can be seen from the activities of teachers in carrying out character education programs, namely as program implementers to welcome students so that the picket teacher has to leave earlier than students, as implementers in vocational programs, as executors of the program to collect pedestrians and distribution to communities in need, duha prayer training program implementers from starting to welcome, conditioning in the field, giving good lectures, guiding and controlling the implementation of the sunnah duha prayer, and as the implementer of the Friday infaq program starting from collecting, collecting data, to managing funds.

Furthermore, the role of the school guard is a supporting component in the achievement of the implementation of character education at SDN 5 Sindangkasih. The discipline of school guards is a major factor supporting the success of the implementation of character education. In this case, the school guard has a role in preparing all the equipment or needs of the teacher in order to succeed in implementing the school program. The activities of school guards in character education programs are opening the gate after subuh prayer, cleaning in the school environment, preparing equipment for the implementation of character education programs, and assisting the needs of the teachers at SDN 5 Sindangkasih.

\section{Integrating Character Education at Sindangkasih Elementary School 5}

Implicitly eighteen character values

have been implemented at SDN 5 Sindangkasih through habituation in the programs implemented by SDN 5 Sindangkasih. Thus, character education implemented by SDN 5 Sindangkasih is a conscious effort carried out by the school in order to instill character values to students through habituation summarized in school programs. This is in line with the opinion of Lickona (in Easterbrooks \& Scheets, 2004:255-263) that, "Character education is the deliberate effort to develop the virtues that are good for the individual and good for society". Thus, it is clear that character education is a systematic effort to develop virtues that positively impact both individuals and the social environment, and the process is not instantaneous, but through continuous effort (habituation).

Based on the results of data analysis on the values of character education, it can be seen that Sindangkasih Elementary School 5 emphasizes the implementation of religious character values, because religious knowledge is the first foundation in building students' morality towards a better direction. This is in line with Ainiyah's opinion (2013:36) that "religious education is the main pillar of character education". Based on this statement, it is reasonable if SDN 5 Sindangkasih is very enthusiastic in its effort to instill religious values in each student 
through habituation in character education programs.

In addition to religious character, SDN 5 Sindangkasih also emphasizes the cultivation of disciplinary character values and responsibilities. It was felt necessary to do this, because of the negative influence of this global era including the rampant behavior of indiscipline and the lower sense of responsibility of someone towards something. The statement, in line with Apriani's opinion (2015:14) that, "The problems at the moment, include the indiscipline of indiscipline behavior and low sense of individual responsibility".

In this case, SDN 5 Sindangkasih strives to minimize the negative impact of the current global era, through habituation programs to shape the character of students in a better direction. In addition to the character values above, the school also emphasizes the values of independent, communicative and respectful character. This is a proof that SDN 5 Sindangkasih wants to produce independent graduates with all the abilities possessed by students, through giving motivation and habituation to students to be confident.

In addition to being independent, it is also done habituation to instill communicative values through habituation of group discussions, so that students are accustomed to expressing their opinions and / or ideas. These characters are also supported by the cultivation of character values to appreciate achievement, so that each student is able to give a sweet smile to each other, not to smile with a cynical smile, and to nurture each other not to insult each other. Thus, there will be a generation that educates, loves peace, and cares for the environment and social.

\section{CONCLUSSION}

State primary school 5 Sindangkasih has implemented character-based character education on a daily basis to produce character generation.

Character education is a conscious effort by educators to form learners to be able to know something good and bad, understand the nature of goodness that covers its impact on the surrounding environment, and able to internalize the values of good in everyday life both from attitude and behavior.

Character education is implemented through customized habituation in a continuous school program to produce optimal change.

Based on the condition of character education implementation in school, state primary school 5 Sindangkasih shows that the role of all parties include principals, teachers, school employees, parents of learners, students, the police, and the transportation department strongly supports the implementation of character education programs optimally .

\section{REFERENCES}

Ainiyah, N. (2013). Character Building Through Islamic Religious Education. IAIN Gorontalo: Jurnal Al-Ulum.

Apriani, A. (2015). The Effect of ThematicIntegrative SPP on the Character of Discipline and Responsibility of Third Grade Elementary School Students. UNY Journal: Prima Edukasia Journal.

Bungin, B. (2014) Qualitative Research: Communication, Economics, Public Policy, and Other Social Sciences. Jakarta: Kencana.

Easterbrooks, S. R. \& Nanci A. S. (2004). Applying Critical Thinking Skill to 
Character Education and Value Clarification With Student Who Are Dearf or Hard Hearing. JSTOR: American Annals of The Deaf.

Erawati, A. (2013). Environmental Conservation Efforts Through Islamic Education. Yogyakarta: Student Library.

Fuad, A. \& Kandung S. N. (2014). Qualitative Research Practical Guide. Yogyakarta: Graha Ilmu.

Hadianti, L. S. (2008) Effect of Implementation of School Rules on Student Learning Discipline. UNIGA: Journal of Education.

Hidayat, S. (2013). The Effect of Cooperation between Parents and Teachers on Students' Discipline in Jagakarsa Junior High School. Mercubuana: Widya Scientific Journal.

Horn, S. S., Christopher D. \& Melanie K. (2008). Peer Relationship and Social Group: Implications for Moral Education in Nucci, Larry P. \& Darcia Narvaez. Handbook of Moral and Character Education: School, Community, and Moral Education. New York: Routledge.

Hurlock, E. B. (2015). Developmental Psychology: An Approach Along the Range of Life, transfer the Istiwidayanti and Soedjarwo languages. Jakarta: Erlangga.

Izudin, M. (2014). The Role of the "Economic" Independent Smile Program in Efforts to Increase Economic Rates of Mustahiq. IAIN Semarang: Eprints.

Judiani, S. (2010). Implementation of Character Education in Primary Schools Through Strengthening
Curriculum Implementation. Journal of Education and Culture.

Kusnaedi. (2013). Character Education Strategy and Implementation: A Guide for Teachers and Parents. Bekasi: Duta Media Tama.

Lestari, A. (2011). Islamic view of the carrying factors and environment in human formation. Educational Journal of Garut University.

Lickona, T. (2001). What Is Good Character? Research Gate: Reclaming Children and Youth.

Ministry of Religion. (2016). Al-Qur'an and Translation. Jakarta: Syamil.

Moleong, L. J. (2014). Qualitative Research Methodology. Bandung: Adolescent Rosdakarya.

Nisafani, A. S. (2014). Wikibudaya Analysis and Design in Order to Preserve National Culture and Archipelago Local Wisdom. ITSN: Journal Isfo.

Ratnawati, D. (2015). Factors Affecting the Education of Holistic Character Students of Vocational Schools in Malang City. Vocational Park Journal

Rosinta, \& Rosman H. (2018). Knowledge Sharing Behavior at the Al-Fatah Islamic Student Activity Unit (UKMI) at Lancang Kuning University. Unilak Journal: Cultural Library.

Setiyati, S. (2014). The Effect of School Principal Leadership, Work Motivation, and School Culture on Teacher Performance. UNY Journal: Technology and Vocational Education.

Slavin, R. E. (2011) Educational Psychology: Theory and Practice, Marianto Samosir Translation. Jakarta: Index. 
Sumantri, M. S. (2016) Learning Strategies: Theory and Practice at the Basic Education Level. Jakarta: RajaGrafindo.

Wulandari, H. (2017). Fostering Character Education Through Atikan Purwakarta in Early Childhood Education. Journal of Didactic.

Zubaedi. (2015). Character Education Design: Conception and Application in Educational Institutions. Jakarta: Kencana. 